\title{
Peran Pemerintah Desa Dalam Perubahan Pariwisata Osing di Desa Kemiren Kecamatan Glagah Kabupaten Banyuwangi
}

\author{
Anastasia Murdyastuti ${ }^{1}$, Nur Aini Mayasiana \\ anastasia.fisip@unej.ac.id
}

\begin{abstract}
Banyuwangi Regency is actively developing tourism potential, one of which is osing culture because it is unique and exciting as part of osing community life which is very obedient and obedient to cultural values. Still, the osing community is dynamic so that the existence of osing culture which was only as a traditional ceremonial tradition, is now packaged into more interesting material that can be a spectacle that can be sold. The change is inseparable from the role of the village government to invite the public and the private sector to jump into more advanced conditions and even become a leading tourism object in Banyuwangi Regency. The research method used is qualitative, and data collection techniques by observation, documentation, and interviews - analysis of data with interactive models through data collection data presentation data reduction and concluding.

The results showed that the role of the government in making changes was quite good as seen from changes in tourist attractions and attractions, amenities and accommodation, accessibility, and tourism image osing already adequate, complete and good condition, because of the similarity in seeing the same future in advancing its village, trusting and making changes with specific actions between the private government and the community, although there are still limited funds and differences in interests, the government provides consistent support and basis so as to demonstrate a mutually supporting synergy.
\end{abstract}

Keyword: Role, village government, change, and tourism osing

\begin{abstract}
Abstrak
Kabupaten Banyuwangi secara aktif mengembangkan potensi wisata, salah satunya adalah budaya osing karena unik dan menarik sebagai bagian dari kehidupan masyarakat osing yang sangat taat dan taat pada nilai-nilai budaya. Meski demikian, komunitas osing bersifat dinamis sehingga keberadaan budaya osing yang tadinya hanya sebagai tradisi upacara adat, kini dikemas menjadi materi yang lebih menarik sehingga bisa menjadi tontonan yang bisa dijual. Perubahan itu tidak terlepas dari peran pemerintah desa untuk mengundang publik dan sektor swasta untuk terjun ke kondisi yang lebih maju dan bahkan menjadi objek wisata terkemuka di Kabupaten Banyuwangi. Metode penelitian yang digunakan adalah kualitatif, dan teknik pengumpulan data dengan observasi, dokumentasi, dan wawancara - analisis data dengan model interaktif melalui pengumpulan data penyajian data reduksi dan penarikan data.

Hasil penelitian menunjukkan bahwa peran pemerintah dalam melakukan perubahan cukup baik dilihat dari perubahan tempat wisata dan atraksi, fasilitas dan akomodasi, aksesibilitas, dan citra pariwisata yang sudah memadai, kondisi lengkap dan baik, karena adanya kesamaan dalam melihat masa depan yang sama dalam memajukan

1 Universitas Jember
\end{abstract}


desanya, mempercayai dan membuat perubahan dengan tindakan spesifik antara pemerintah swasta dan masyarakat, meskipun masih ada dana terbatas dan perbedaan kepentingan, pemerintah memberikan dukungan dan dasar yang konsisten sehingga dapat menunjukkan sinergi yang saling mendukung.

Kata Kunci: Peran, pemerintah desa, perubahan, dan osing pariwisata.

\section{Pendahuluan}

\section{Kabupaten Banyuwangi} merupakan salah satu kabupaten yang gencar mengembangkan pariwisata karena memiliki potensi budaya yang sangat kaya. Selain itu, letak daerah yang berdekatan dengan pulau Bali memiliki peluang untuk pengembangan pariwisata yang lebih maju. Melalui konsep ecotourism pembangunan pariwisata menekankan pada potensi alam dan seni buadaya secara berkelanjutan. Salah satu potensi yang diunggulkan adalah budaya osing di desa Kemiren dimana masyarakatnya sangat patuh dan taat pada nilai budaya osing dalam menjaga kelestarian. Budaya osing sudah ada sejak lama dan hingga kini masih menjadi bagian kehidupan masyarakat kemiren sebagai karya cipta yang indah dan murni, namun juga dinamis sehingga tidak hilang dari pengaruh budaya barat yang dianggap lebih modern. Budaya Kemiren sangat unik dan memiliki daya tarik yang besar dengan karakteristik yang berbeda dibanding suku lainnya di Jawa Timur sehingga menarik untuk potensi wisata seni/budaya, alam maupun buatan.

$$
\text { Budaya osing banyak }
$$
mengalami perubahan untuk mampu bertahan, yang dulu hanya bagian dari adat masyarakat osing sekarang dikemas secara baik sehingga menjadi objek wisata yang bisa dinikmati dan dirasakan kemanfaatan dalam kehidupan manusia. Budaya osing sudah masuk agenda tahunan kegiatan pariwisata Kabupaten Banyuwangi sehingga bisa dijual dan dinikmati wisatawan. Perubahan tersebut bukan suatu yang tiba-tiba, namun tidak lepas dari peran pemerintah yang sangat besar dalam mengembangkan pariwisata yang bekerja sama dengan masyarakat dan swasta. Banyak pemain termasuk pemerintah, swasta maupun masyarakat dan dunia bekerja keras mempertahankan suatu budaya karena perubahan akan mencerminkan tuntutan baru dan akan melahirkan elite bangsa.

Pemerintah sangat giat memajukan budaya kemiren untuk menyesuaikan dengan perkembangan yang ada sehingga potensi budaya osing sudah bisa djual, dinikmati maupun yang masih alami. Budaya osing mengalami perubahan yang pesat bukan hanya karena didasarkan pada kepentingan masyarakat lokal tetapi juga pada kemampuan mereka menyediakan tenaga dan modal sosial yang lain (Brohman, 1996: 60). Kondisi tersebut hanya akan terwujud jika pemerintah ikut berperan dalam perubahan karena berdasarkan peraturan menteri desa No. 1 Tahun 2015 menyebutkan bahwa desa berkewajiban untuk pemanfaatan sumberdaya alam dan lingungan desa. Pemerintah mempunyai kewajiban menjaga dan mengembangkan kebudayaan suatu daerah agar tidak hilang dari pengaruh budaya lain. Budaya yang memiliki prospek yang menguntungkan harus didukung untuk pengembangan wisata yang memadahi sehingga menjamin peningkatan pendapatan daerah dan meningkatkan 
peluang kerja bagi warganya. Dan untuk melihat peran yang dilakukan pemerintah dalam perubahan budaya osing agar lebih berkembang dan bermanfaat maka tema ini menarik untuk diteliti terkait bagaimana peran pemerintah dan perubahan apa yang dilakukan untuk menjaga budaya osing di desa Kemiren.

\section{Tinjauan Pustaka}

\section{Konsep Organisasi Pemerintahan Desa}

Thoha menjelaskan bahwa organisasi merupakan kerangka hubungan yang berstruktur yang menunjukkan wewenang, tanggung jawab dan pembagian kerja untuk menjalankan fungsi tertentu. (2003:124). Organisasi merupakan suatu batasan-batasan tertentu dengan demikian seseorang yang melakukan hubungan interaksi dengan lainnya tidak atas kemauannya sendiri melainkan dibatasi oleh aturan-aturan. Sedangan desa adalah kesatuan hukum yang memiliki kewenangan untuk mengurus rumah tangganya sendiri berdasarkan hak asal usul dan adat istiadat yang diakui dalam pemerintahan nasional dan berada dibawah kabupaten. (Widjaja: 2003:165). Pemerintahan desa sebagai organisasi terendah yang memiliki otonomi untuk mengelola pemerintahannya sendiri sesuai kemampuannya.

Pemerintahan desa sebagai organisasi harus menggambarkan hubungan kerja orang-orang yang juga didasarkan pada peraturan. Menurut UU No. 6 Tahun 2014 Pemerintahan desa adalah penyelenggaraan urusan pemerintahan dan kepentingan masyarakat setempat dalam dalam sistem pemerintahan negara kesatuan RI. Untuk menyelenggarakan pemerintahan itu maka desa memiliki kewenangan untuk menjalankan peran.

\section{Peran}

Pemerintah desa adalah kepala desa yang dibantu oleh perangkat desa sebagai unsur penyelenggara pemerintahan desa. Dalam menjalankan tugasnya pemerintah desa memiliki peran. Peran menurut Soerjono (2002:260) adalah merupakan aspek dinamis dari kedudukan apabila seseorang melaksanakan hak-hak dan kewajibankewajibannya sesuai dengan kedudukannya maka dia menjalankan suatu peranannya. Peran pemerintah desa adalah merupakan seluruh kegiatan dan penyelenggaraan desa yang dilaksanakan oleh pemerintah desa dan BPD sebagai organ yang berwenang memproses pelayanan yang baik bagi masyarakat melalui hubungan pemerintahan desa sehingga setiap anggota masyarakat yang bersangkutan menerima sebagai seorang yang memerintah pada saat yang diperlukan sesuai tuntutan (harapan) yang diperintah (masyarakat). Hal ini artinya seseorang yang berkedudukan sebagai pemerintah desa telah melakukan perannya dalam masyarakat. (Soekarno (2002:243)

Dalam menjalankan perannya pemerintah desa selalu melakukan perubahan (Change) dalam aspek pelayanan, pembangunan maupun pemerintahan. Berdasarkan UU No. 6 Tahun 2014 dinyatakan bahwa Kepala Desa bertugas menyelenggarakan pemerintahan desa melaksanakan pembangunan desa dan pembinaan masyarakat serta pemberdayaan masyarakat. Osing sebagai potensi yang berharga sudah seharusnya menjadi tugas pemerintah desa untuk menjaga dan mengembangkan agar 
memberi manfaat pada masyarakat dan pemerintah.

\section{Change (Perubahan)}

Perubahan adalah keadaan yang berubah. Atau peralihan keadaan yang sebelumnya. Perubahan adalah merupakan transformasi dari keadaan yang sekarang menuju keadaan yang diharapkan di masa yang akan datang, suatu keadaan yang lebih baik (Kamus Bahasa Indonesia). Change (perubahan) adalah bagian penting dari manajemen dan keberhasilan seorang pemimpin diukur dari kemampuannya memprediksi perubahan dan menjadikan perubahan tersebut suatu potensi. Perubahan adalah esensi dan pertanda kehidupan. Dengan kehidupan maka setiap hari diyakinkan bahwa gerak, dinamika dan perubahan-perubahan adalah bagian dari keduanya. Oleh karena itu kehidupan yang harus dilalui dan hanya mereka yang mampu melakukan adaptasi dengan perubahan yang mampu melewati kurve tersebut. Berdasarkan teori Barabba dalam Kasali (2005: xxxiii) bahwa manusia akan berselancar pada kurve $\mathrm{S}$ (sigmoin curve) dan untuk menikmati perubahan manusia harus melompat dari satu kurve ke kurve baru. Pada perubahan itulah manusia akan berpindah ke zona kenyamanan (comford zona) ke zona ketidaknyamanan (discomfort zona). Perubahan harus melawan naluri atau sejarah sehingga jika tidak kuasa akan mati.

Perkembangan IPTEK mengakibatkan perubahan di segala aspek kehidupan dan untuk mengarah pada kemajuan yang lebih baik maka perlu peran berbagai pihak terutama pemerintah sebagai agen pe-ubah. Dalam teori perubahan menurut
Beckhard dan Harris, 1987 yang dikutip Kasali, 2005, menganjurkan agar fokus kedepan daripada berbicara rentang masa lalu yang telah memberikan dampak negatif. Pemikiran tersebut untuk:

1. memberikan semangat dan membuang perasaan pesimis

2. mendorong orang-orang yang menentukan perannya dalam perubahan dan menciptakan kepatuhan

3. mengurangi ketidakpuasan dan perasaan-perasaan tidak nyaman.

Dengan perubahan memberikan fokus perhatian pada upaya-upaya mengatasi masalah keseimbangan pada symptomsymptom untuk membuat kegiatan dan organisasi bekerja secara efektif. Memang tidak semua perubahan membawa pembaharuan, hal tersebut terjadi jika:

1. Kepemimpinan tidak cukup kuat

2. Salah melihat reformasi

3. Sabotase di tengah jalan

4. Komunikasi yang tidak baik

5. Masyarakat yang tidak mendukung

6. Proses buy-in tidak berjalan

Karakteristik change menurut (Kasali: 2005) adalah:

1. Ia begitu misterius karena tak mudah dipegang. Bahkan yag sudah dipegang pun tak bisa pergi ke tempat lain tanpa berpamitan. Ia bahkan memukul balik seakan tak kenal budi.

2. Memerlukan change marker(s). Pemimpin yang lakukan perubahan tidak dilakukan sendiri tapi punya keberanian yang luar biasa.

3. Tak semua orang bisa diajak melihat perubahan bahkan sebagian orang hanya melihat memakai mata persepsi. 
4. Perubahan terjadi setiap saat maka perubahan harus diciptakan setiap saat pula.

5. Ada sisi keras (uang dan teknologi) dan sisi lembut (orang dan organisasi) dalam perubahan

6. Perubahan membutuhkan waktu biaya dan kekuatan

7. Dibutuhkan upaya-upaya khusus untuk menyentuh nilai-nilai dasar organisasi (budaya korporet). Tanpa menyentuh nilai-nilai dasar perubahan tidak akan mengubah perilaku dan kebiasaan-kebiasaan

8. Perubahan banyak diwarnai mitos Perubahan menimbulkan ekspektasi dan kebenaran ekpektasi dapat menimbulkan getaran-getaran emosi dan harapan yang bisa menimbulkan kekecewaan-kekecewaan

9. Perubahan selalu menakutkan dan menimbulkan kepanikankepanikan. (Kasali, 2005: xxxiiixxxv)

\section{Budaya Osing}

Pariwisata adalah istilah yang diberikan apabila seseorang wisatawan melakukan perjalanan itu sendiri atau aktivitas dan kejadian ketika seseorang pengunjung melakukan perjalanan (Yoeti, 1997). Pariwisata adalah kegiatan dalam masyarakat yang berhubungan dengan wisatawan (Soekatijo. 2000:2). Perubahan sektor kepariwisataan menjadi kajian yang menarik saat ini terutama dalam upaya untuk mengoptimalkan potensi pariwisata agar memberi kenikmatan dan kepuasan para pengunjung. Osing merupakan budaya Banyuwangi yang sangat diunggulkan karena potensinya yang unik dan menarik sehingga keberadaannya menarik wisatawan. Pemkab Banyuwangi beserta masyarakatnya memiliki komitmen yang tinggi untuk menjaga dan melestarikan serta mengembangkan budaya osing dengan melakukan perubahan-perubahan. Upaya yang dilakukan adalah:

1. Budaya osing sangat penting yang harus dijaga dan dilestarikan,

2. Budaya osing harus dikemas lebih menarik agar menjadi pusat wisata Banyuwangi sehingga memberi dampak positif pada masyarakatnya.

3. Meskipun nilai agama, adat dan kebiasaan berbeda hendaknya saling menjaga satu sama lain dan bersinergi sehingga tidak menimbulkan pertentangan.

4. Memberi ruang yang proporsional kepada pihak-pihak terkait untuk berpartisipasi dalam pengembangan wisata osing.

Pemerintahan desa dalam menjalankan tugas khususnya bidang pariwisata berperan besar dalam melakukan perubahan sehingga wajah osing menjadi lebih cantik dan menarik, sehingga bisa dinikmati dan memberikan keuntungan baik secara ekonomi sosial maupun budaya. Maka dalam perubahan perlu memperhatikan aspek-aspek tersebut. Perubahan kepariwisataan akan mencapai kodisi yang baik jika:

1. Memenuhi ketersediaan objek dan daya tarik wisata

2. Ketersediaan akses yang dibutuhkan pengunjung

3. Ketersediaan fasilitas kepariwisataan untuk keperluan pelayanan masyarakat. 


\section{Metode Penelitian}

Metode penelitian merupakan cara ilmiah yang merupakan suatu cara yang berkaitan dengan cara kerja untuk memahami suatu subjek atau objek penelitian. Untuk menemukan suatu jawaban yang dapat dipertanggungjawabkan secara ilmiah termasuk keabsahannya.

Jenis penelitian ini adalah penelitian kualitatif dan lokasi penelitian dilaksanakan di Desa Kemiren Kecamatan Glagah Kabupaten Banyuwangi. Pengumpulan data secara observasi wawancara dan dokumentasi. Informan penelitian adalah Kepala Desa, Sekdes, Perangkat Desa, BPD dan pokdarwis serta masyarakat pelaku perubahan. Sedangkan analisis data dilakukan dengan model interaktif melalui pengumpulan data penyajian data reduksi data dan penarikan kesimpulan (Uber Silalai, 2012: 20).

\section{Pembahasan}

\section{Gambaran Kabupaten Banyuwangi}

$\begin{array}{ccr}\text { Kabupaten } & \text { Banyuwangi } \\ \text { merupakan salah satu kabupaten }\end{array}$ paling ujung timur Propinsi Jawa Timur yang berdekatan dengan Propinsi Bali sebagai pusat pariwisata dunia sehingga memiliki dampak yang cukup besar terhadap perkembangannya. Pemerintahan Kabupaten Banyuwangi terbagi menjadi 24 Kecamatan, 28 Kelurahan dan 189 desa, 2.839 RW dan 10.569 RT. Jumlah pegawai sebesar 14.525 orang terdiri 8.761orang laki-laki dan 5.764 orang perempuan. Pegawai golongan IV sebanyak 5.605 orang (38,59\%), golongan III sebanyak 5.546 orang $(38,19 \%)$, golongan II sebanyak 2.931 orang $(20,17 \%)$ dan golongan I sebanyak 443 orang atau 3,05 \%). Pariwisata di Kabupaten Banyuwang bertajuk The Sunrise of Java ini mendapatkan penghargaan Travel Club Tourism Award (TCTA) 2012, sebagai kota/kabupaten memiliki komitmen tinggi dalam mewujudkan tata kelola pengembangan kepariwisataan yang bermutu. Salah satu produk yang diunggulkan di Kabupaten Banyuwangi dengan nilai daya tarik bagi wisatawan yaitu kebudayaan suku osing. Pemerintahan Kabupaten Banyuwangi melalui programnya ingin menjadikan kawasan osing sebagai salah satu produk utama tujuan wisata di Kabupaten Banyuwangi.

\section{Gambaran Desa Kemiren, Kecamatan Glagah, Kabupaten Banyuwangi}

Desa Kemiren dibatasi oleh: Bagian utara Desa Jambesari, Kecamatan Giri, Sebelah selatan berbatasan dengan Desa Olehsari, Kecamatan Glagah, Sebelah Timur berbatasan dengan Desa Banjarsari, Kecamatan Glagah dan sebelah barat berbatasan dengan Desa Taman Suruh, Kecamatan Glagah. Luas Wilayah desa Kemiren kurang lebih $177,052 \mathrm{~m}^{2}$. Terdiri sekitar 13,200 ha untuk perumahan atau pekarangan, 127,200 ha untuk lahan pertanian (sawah dan ladang), 1,250 digunakan untuk sarana jalan, 4,250 ha digunakan untuk sarana pemakaman, 0,651 ha digunakan untuk sarana bangunan umum, dan tempat rekreasi.

Desa Kemiren memiliki potensi alam yang bagus karena desa Kemiren termasuk daerah lereng pegunungan Ijen, sekitar $30 \mathrm{~km}$ dari desa Kemiren kearah barat. Wilayah 
tanah desa Kemiren sebagian bergelombang dengan ketinggian tempat sekitar antara 100-144 meter di atas permukaan laut. Tempat terendah kurang lebih dasar sungai, sedang tempat-tempat tertinggi berupa tanah-tanah yang membukit sehingga desa Kemiren memiliki potensi menarik untuk dijadikan tempat rekreasi. Saat ini desa Kemiren banyak dibangun tempat rekreasi buatan sebagai potensi wisata adalah:

1. Taman Rekreasi Anjungan wisata Using yang dilengkapi Cottage dan Kolam Renang

2. Sanggara Kesenian yang meliputi sanggar Barong Trisno Budoyo, Sanggar Kesenian Barong Lancing Sapu Jagad, serta Sanggar Genjah Arum
Keistemewaan Wisata Osing adalah pada kekhasan kehidupan dan pemukiman penduduk serta adatistiadat suku Osing. Menurut Kepala Bidang Kebudayaan Dinas Kebudayaan dan Pariwisata Setiyo Puguh: menyatakan bahwa Wisata using adalah wisata budaya dan seni dari masyarakat using, sementara fasilitas rekreasi hanya merupakan tambahan yang dibangun sebagai pelengkap.

Potensi Budaya yang terdapat di Desa Kemiren cukup banyak diantaranya: Barong Ider Bumi Tumpeng Sewu Rebo Wekasan, Selamatan Rajab, Ruwah, Sawalan, Kopatan, Suroan, Mocoan Lontar Yusuf, Obor Blarak, Godogan, Angklung Caruk, Mepe Kasur.

Tabel 1. Jumlah Sanggar

\begin{tabular}{|l|l|l|l|}
\hline No. & \multicolumn{1}{|c|}{ Nama Sanggar } & \multicolumn{1}{|c|}{ Pemilik } & \multicolumn{1}{c|}{ Produksi } \\
\hline 1 & Sapu Jagad & Pak Sucipto & Kesenian Barong, Gandrung \\
\hline 2 & Cindesutra & $\begin{array}{l}\text { Pak Agus } \\
\text { Riyanto }\end{array}$ & $\begin{array}{l}\text { Gamelan osing, angklung caruk, } \\
\text { kuliner dan tari-tarian }\end{array}$ \\
\hline 3 & Tresno Budoyo & Pak Pendik & $\begin{array}{l}\text { Batik, Pakain adat, tari-tarian, } \\
\text { barong }\end{array}$ \\
\hline 4 & $\begin{array}{l}\text { Rumah Budaya } \\
\text { Osing }\end{array}$ & Pak Purwadi & $\begin{array}{l}\text { Mocoan LontarYusup dan Kajian } \\
\text { Kebudayaan Osing }\end{array}$ \\
\hline 5 & Genjah Arum & Pak Iwan & $\begin{array}{l}\text { Kopi, Godhongan, Tari-Tarian, } \\
\text { Angklung dKuliner }\end{array}$ \\
\hline 6 & Mbok Temuk & Bu Temuk Misti & Tari-Tarian \\
\hline 7 & $\begin{array}{l}\text { Pesantongan } \\
\text { Kemangi }\end{array}$ & BUMDes & Kuliner dan Kopi \\
\hline
\end{tabular}

Sumber Data: Pokdarwis Desa Kemiren, 2018.

\section{Peran Pemerintah dalam Perubahan Pariwisata Osing di Desa Kemiren}

Dalam perubahan pariwisata osing tidak lepas dari peranan berbagai pihak berdasarkan prinsip sapta pesona yang melibatkan 4 pihak yaitu pemerintah, swasta masyarakat dan pokdarwis dalam melakukan perubahan dan pengembangan yang menjalin keterkaitan. Peran pemerintah termasuk dalam menyediakan peraturan sebagai dasar aturan dan memberikan dukungan kegiatan perubahan dan 
perkembangan pariwisata di desa Kemiren sehingga menjadi lebih terarah dan berkembang. Sementara swasta menyediakan fasilitas dan masyarakat dan pokdarwis lebih banyak melaksanakan aktivitas terkait perubahan yang sudah ditetapkan dalam peraturan. Kegiatan yang dilakukan meliputi peningkatan SDM, pemasaran, peningkatan apresiasi dan pembangunan tempat wisata. Dalam menjalankan peran pemerintah desa banyak melakukan perubahan untuk mengemas pariwisata di desa Kemiren menjadi lebih maju yaitu dengan mengembangkan potensi wisata menjadi lebih menarik dan laku dijual. Bahkan sudah diagendakan dalam acara tahunan pemerintah daerah yang sifatnya rutin sehingga secara fisik desa Kemiren menjadi lebih menarik. Di samping itu, secara ekonomi masyarakat banyak mendapatkan peningkatan ekonomi, seni budaya tumbuh subur dan alam dibenahi secara cantik. Keberhasilan tersebut berkat kerjasama dengan BPD dan pokdarwis yang bekerja sama dengan baik dalam pengelolaan pariwisata di desa Kemiren. Perubahan tersebut tidak semuanya berdampak positif karena banyak pengorbanan perjuangan dan kerugian yang dirasakan oleh berbagai pihak. Kepala Desa beserta perangkatnya selaku penyelenggara pemerintahan harus berani berinovasi dan berkreasi untuk melakukan perubahan yang terkadang mendapat cibiran kerugian dan bahkan kegagalan. Misalnya dalam mengemas paket wisata untuk memadukan berbagai kepentingan tidak jarang sering mendapat pertentangan atau kritikan atau bahkan perlawanan yaitu ketika menentukan jadwal pengisi acara atau substansi acara yang akan disuguhkan. Kegagalan atau kendala tersebut bisa diatasi secara musyawarah dari berbagai pihak berkat pemahaman dan kepentingan bersama.

Di sektor pemerintahan memang sulit untuk berubah dan akan sangat berbeda dengan bisnis yang mudah berubah. Tetapi perubahan makro akan merubah perubahan mikro. Dunia pariwisata yang berubah secara makro mau tidak mau secara mikro harus berubah seiring tuntutan kebutuhan yaitu dimana desa dengan potensi yang dimiliki akan mampu memajukan desanya pula. Untuk melakukan perubahan bukan sesuatu yang mudah karena untuk berubah manusia harus diajak melihat dan mempercayai bahwa sesuatu telah berubah. Dalam keseharian manusia akan bergerak pada kurve tertentu $S$ (Sigmoid Curve). Untuk menikmati perubahan manusia harus melompat dari satu kurve ke kurve lain yang baru. Pada saat itu manusia berpindah pada zona kenyamanan (Confort zona). Ini manusia harus melawan naluri-nalurinya melawan sejarah hidupnya jika tak kuasa maka akan lentur dan mudah patah. Dan itulah terkadang orang memilih membiarkan diri atau organisasinya menjadi tua dan mati daripada berpindah ke kurve kedua. (Vincent P. Barabba, dalam Kasali, 2005:7). Berdasarkan teori tersebut pemerintah desa berhasil melakukan perubahan yang ditunjukkan oleh peran pemimpin yaitu bupati yang sangat visioner dan kepada desa beserta perangkat, swasta, pokdarwis dan masyarakatnya bekerja untuk membuat format baru agar budaya osing tetap bertahan, lebih modern dan maju sehingga tanpa menghilangkan keunikannya dan tetap memiliki makna yang sama.

Hasil penelitian menunjukkan bahwa peran pemerintah dalam melakukan perubahan nampak pada: 
1. Atraksi dan daya tarik wisata, dimana budaya osing dikemas melalui bentuk atraksi yang modern dan menambah dengan atraksi wisata yang lain. Meskipun terkadang harus meninggalkan ketentuan tradisi untuk diubah sesuai tuntutan pasar.

2. Amenitas dan akomodasi banyak perubahan fasilitas menjadi lebih lengkap dan baik.

3. Aksesibilitas menuju wisata osing sudah cukup lancar dan bagus sehingga memudahkan pengunjung meskipun untuk angkutan umum belum terfasilitasi.

4. Citra wisata (image) melalui promosi baik melalui media elektronik juga pemasangan baleho maupun program pemerintah maupun informasi dari mulut ke mulut.

Kekuatan pemerintah dalam menjalankan peran dalam perubahan di dunia pariwisata karena adanya kesamaan dalam melihat masa depan yang sama dalam memajukan desanya, mempercayai dan melakukan perubahan dengan tindakan yang pasti antara pemerintah swasta dan masyarakat. Pemerintah daerah bersama pemerintah desa memberikan dukungan dan dasar aturan yang konsisten swasta membantu fasilitas dan masyarakat menyediakan potensinya sehingga menunjukkan sinergi yang saling mendukung.

\section{Kesimpulan}

Kesimpulan dalam penelitian ini yaitu peran pemerintah dalam melakukan perubahan pariwisata osing menunjukkan hasil yang cukup baik karena pariwisata osing menjadi bagian agenda pemerintah, memiliki paket wisata yang dikemas secara baik. Perubahan dapat dilihat dari perubahan atraksi dan daya tarik wisata, amenitas dan akomodasi, aksesibiltas, dan citra wisata osing sudah memadai, lengkap dan kondisi baik. Hal tersebut karena adanya kerja sama yang baik dengan masyarakat dan pemerintah, adanya kesamaan dalam melihat masa depan yang sama dalam memajukan desanya, mempercayai dan melakukan perubahan dengan tindakan yang pasti antara pemerintah swasta dan masyarakat, meskipun masih ada keterbatasan dana dan perbedaan kepentingan yang masih harus disesuaikan, namun pemerintah memberikan dukungan dan dasar aturan yang konsisten sehingga menunjukkan sinergi yang saling mendukung.

\section{Daftar Pustaka}

A Yoeti, Oka, 1996, Pengantar Ilmu Pariwisata, Bandung Penerbit Angkasa

Brohman, J., 1996, New Directions in Tourism for Third world Deveompment, Annas of Tourism Research, Vol 23 No.1, Hal 68.

E. Maryani, 1991, Pengantar Geografi Pariwisata, Bandung; Pendidikan Geografi FPIPS IKIP Bandung

Kasali, Renald, Change, 2005, Jakarta, Penerbit PT Gramedia Pustaka Utama

Nyoman S. Pendit, 2002, Ilmu Pariwisata Sebuah Pengantar, Perdana, Jakarta, PT Pradnya Paramita 
Norcholis, Hanif, 2011, Pertumbuhan dan Penyelenggaraan Pemerintah Desa, Jakarta Penerbit Erlangga.

Moleong Lexy J, 2014 Metode Penelitian Kualitatif, Bandung PT Remaja Rosdakarya.

Sunaryo, Bambang 2013, Kebijakan Pembangunan Destinasi Pariwisata Konsep dan Aplikasinya Di Indonesia, Yogyakarta Gava Media

Soekatijo, 2000, Anatomi Pariwisata, Jakarta Gramedia

Silahuddin, 2015, Kewenangan Desa dan Regulasi Desa, Jakarta, Kementerian Desa Pembangunan Daerah Tertinggal dan Transmigrasi RI.

Silalahi, Uber 2012, Metode Penelitian Kualitatif Dalam Perspektif Rancangan Penelitian, Yogyakarta Ar-Ruzz Media.

Soekanto, Soerjono, 2002, Teori Peranan, Jakarta Bumi Aksara
Soekatijo. 2000, Anatomi Pariwisata Jakarta Granmedia

Thoha, 2003, Perilaku Organisasi Konsep Dasar dan Aplikasinya, Jakarta Raja Grafindo Persada

Wijaya AW, 2000, Otonomi Desa Merupakan Otonomi Asli, Bulat dan Utuh, Jakarta Raja Grafindo Persada.

......, 2005, Penyelenggaraan Otonomi di Indonesia: Dalam Rangka Sosialisasi UU No 32 Tahun $2004 \quad$ Tentang Pemerintahan Daerah, Jakrta Raja Grafindo Persada.

UU RI No. 10 Tahun 2009 Tentang Kepariwisataan

UU No. 6 Tahun 2014 Tentang Desa

Peraturan Menteri Dalam Negeri RI No. 114 Tahun 2014 tentang Pedoman Pembangunan Desa.

Peraturan Daerah Kabupaten Banyuwangi No. 14 Tahun 2017 Tentang Pelestarian Warisan Budaya dan Adat Istiadat di Banyuwangi 